\title{
Hepatocellular steatosis as a response to nutritional stressors in Lutjanus guttatus (Steindachner, 1869) grown in floating cages: a case study
}

\author{
Johnatan A. Ruiz-Ramírez ${ }^{2}$, Eduardo Ramírez-Ayala ${ }^{3}$, Adrián Tintos-Gómez ${ }^{1,3}$ \\ Claudia Salas-Villaseñor ${ }^{4}$, Luis Jorge García-Márquez ${ }^{2}$, Imelda Borja-Gómez ${ }^{1}$ \\ César A. Sepúlveda-Quiroz ${ }^{1}$, Carlos Lezama-Cervantes ${ }^{1}$ \& Alejandro R. Morales-Blake ${ }^{1}$ \\ ${ }^{1}$ Facultad de Ciencias Marinas, Universidad de Colima, Manzanillo, México \\ ${ }^{2}$ Facultad de Medicina Veterinaria y Zootecnia, Universidad de Colima, Tecomán, México \\ ${ }^{3}$ Departamento de Estudios para el Desarrollo Sustentable de la Zonas Costeras \\ Universidad de Guadalajara, Cihuatlán, Jalisco, México \\ ${ }^{4}$ Centro Universitario de los Lagos, Universidad de Guadalajara, Lagos de Moreno, Jalisco, México \\ Corresponding author: Adrián Tintos Gómez (atintos48@gmail.com)
}

\begin{abstract}
This paper describes histological findings in the liver of Lutjanus guttatus after an acute mortality event in fish cultivated by river fishermen from Colima, Mexico, who were making their first attempt to cultivate this species. During 187 days, divided into two stages, 20,000 juveniles $(6 \mathrm{~g})$ were randomly distributed in three floating cages $\left(125 \mathrm{~m}^{3}\right.$ ). During the first 110 days (pre-fattening), the fish were fed commercial feed. From days 111 to 180 (fattening), the fish were given a test feed, high in fat (20.4\%) and low in protein $(30.2 \%)$. At the end of the first stage, the fish showed good biometric parameters as well as normal behavior and healthy appearance. During the second stage, starting on day 175, a strange behavior was observed followed by an acute mortality event; this alarmed the group of fishermen, who requested our intervention. In the necropsy and the histopathological analysis, the liver of the fish showed clear evidence of hepatocellular steatosis, possibly as a result of the nutritional stress to which they were subjected during cultivation. The present work can serve as a basis for future research, given the scarce information of this pathology in this fish species.
\end{abstract}

Keywords: Lutjanus guttatus; mariculture; hepatic lipidosis; nutritional deficiency; lipid pathology; aquaculture

Poor food production in Mexico, including food of marine origin, is part of a complicated scenario that demands the implementation of public policies to support the primary production sector through skills training and/or technological transfer in order to promote the development of social capital and sustainable rural development (Bustillo-García et al., 2008). The snapper Lutjanus guttatus is a demersal species that inhabit coastal reefs up to about $30 \mathrm{~m}$ deep. It is usually solitary but can also be found in small groups and occasionally forms large schools. The juveniles live in estuaries and river mouths (Allen, 1995). This species is distributed from the Gulf of California, Mexico, to Peru (Rojas et al., 2004), and plays an important role in the artisanal fishery. Snapper species with the potential to be used in commercial aquaculture have desirable characteristics, such as being able to live in cages without developing an aggressive behavior (Olivares \& Boza, 1999), accepting pelleted food, having white meat with high acceptance and demand in the market (Cano, 2003; Ibarra-Castro \& Duncan, 2007) and being amenable to reproduction control (Valverde \& Boza, 1999; Cano, 2003).

All aquaculture systems require careful monitoring of all the intrinsic and extrinsic variables related to the growth of the cultivated organisms. In mariculture systems, stressors are present, and can potentially increase, at all times. Providing an adequate feed is the main contributing factor to maintaining a level of wellbeing in fish that allows them to grow at an optimal rate, strengthening their immune system and helping them preserve their homeostatic and allostatic capacity (Segner et al., 2012). However, when response mecha-

Corresponding editor: Fernando Vega 
nisms are pushed beyond their normal limit, the responses become non-adaptive or even harmful to the health of the fish (Barton, 2002). More so, if the intensity of the stressor is severe or lasting, the physiological response mechanisms (allostatic) can become detrimental to the fish's health and well-being (Segner et al., 2012), which is a matter of concern for the aquaculture industry (Barton, 2002).

Since lipid metabolism is mainly regulated by the liver, including the synthesis and degradation of fatty acids, an unbalanced diet could affect the structure and function of the liver (Roberts \& Ellis, 2012); thus, providing an adequate diet to marine fish is especially important (García-Ortega, 2009; Abdo de la Parra et al., 2010).

This paper aims to describe histological findings in the liver of $L$. guttatus specimens after an acute mortality event during a fish fattening experience, which constituted the first approach to the cultivation of this species by a group of fishermen from the coast of Colima, Mexico. It is worth noting that, due to the fishermen's group lack of experience, several technical difficulties arose. The most significant of which was the administration of feed that was not specific for the species, during the first stage (pre-fattening stage), including Silvercup ${ }^{\circledR}$ for shrimp, Nutripec ${ }^{\circledR}$ for catfish and Purina ${ }^{\circledR}$ for trout, which did not meet the necessary nutritional and buoyancy requirements. In the second stage (fattening), the fish were given a test food with proteins and lipids of vegetable origin; during this stage the fish showed abnormal behavior such as not eating, erratic swimming and lethargy, followed by a mortality event that lasted 3 days, alarming the group of fishermen, who requested our intervention to determine the possible causes of these events. To do this, we carried out necropsies and histological analysis of the liver of various dead fish. The culture was conducted in Bahía de Santiago, municipality of Manzanillo, Colima, Mexico from September 2013 to March 2014. A total of 20,000 juveniles of L. guttatus $(6.0 \pm 0.50 \mathrm{~g}$ of weight) were provided by the Center for Research in Food and Development (CIAD-Mazatlán) in Mexico. The juveniles were randomly distributed in 3 floating cages of $125 \mathrm{~m}^{3}$. The cultivation period was divided into two stages, the first from day 1 to day 110 , and the second from day 111 to day 180 . During the first stage (pre-fattening) the organisms were fed ad libitum six times a day with commercial feed for shrimp (Silvercup $^{\circledR}$, P/L 45/9), catfish (Nutripec Purina ${ }^{\circledR}$, P/L 50/15) and trout (Purina ${ }^{\circledR}, \mathrm{P} / \mathrm{L}$ 48/12). During the second stage (fattening), the fish were fed ad libitum but only twice a day and with a test feed made with protein and fat of vegetable origin, the composition of which was not known a priori by the group of fishermen. During the pre-fattening stage the cages were checked and cleaned daily by a diver, from the outside and inside, during the pre-fattening stage, to remove epibionts and maintain the water circulation, as suggested by Hodson et al (1997) and Fitridge et al. (2012), to detect and repair tears in the sock mesh of the cages, and to observe the behavior of the fish before, during and after feeding. Temperature and salinity were read daily using a Sea-Bird 19 plus CTD probe (SeaBird Scientific ${ }^{\circledR}$ WA, USA). Body weight and size data were recorded on days 38, 67, 110 and 187 of the cultivation, for which the fish were caught with a trammel net of $3 \mathrm{~m}^{2}$ (with a mesh size of 0.25 and 2 inches) operated by two divers. After the capture, the fish were anesthetized with clove oil, weighed on a scale (Ohaus model 8010) and measured using an artisanal ichthyometer (the data reported by the supplier of the juveniles at the time of delivery was verified at day zero in a selected sample, as suggested by GarcíaGómez et al., 2002).

The following indices were estimated based on the obtained weight and size data: weight increase WI = final average weight $(\mathrm{g})$ - average initial weight $(\mathrm{g})$; specific growth rate SGR $=100 \times(\ln$ initial weight-ln initial weight) / time); condition factor $\mathrm{K}=$ final weight / total length ${ }^{3}$; average daily weight gain DWG $=$ (final weight-initial weight) / number of days of cultivation. The proximate analysis of the test feed provided during the fattening stage was carried out in the laboratory of the Lagos University Center of the University of Guadalajara, for which 12 random samples of the test feed were taken from the same lot. The composition of lipids, proteins and nitrogen was evaluated using the method described by Kirk et al. (1996).

During the acute mortality event, which started on the 175 of the culture, 48 live juvenile fish were randomly collected for post-mortem analysis. They were examined using the routine technique described by Roberts \& Ellis (2012). Liver samples were taken and fixed in $10 \%$ neutral-buffered formalin for histopathological analysis. The samples were processed following the method of Prophet (1995), cutting the tissue into $4 \mu \mathrm{m}$-thick sections, staining it with hematoxylin and eosin, and mounting it on permanent slides. The average temperature in the culture cages was $28.93^{\circ} \mathrm{C}$, ranging from 26.85 in March to $30.37^{\circ} \mathrm{C}$ in October, with an average salinity of 33.53 , ranging from 33.01 in November to 33.9 in December. Average monthly temperature and salinity values are shown in Table 1. Four biometric measurements were performed during the culture period, three during the pre-fattening stage and one during the development stage.

Table 2 shows the average weight and length of the fish. In the pre-fattening stage, the organisms presented an 
Table 1. Average temperature and salinity of the water during the culture period.

\begin{tabular}{lcc}
\hline Month & $\mathrm{T}\left({ }^{\circ} \mathrm{C}\right)$ & Salinity \\
\hline September & 30.27 & 33.32 \\
October & 30.37 & 33.54 \\
November & 30.24 & 33.01 \\
December & 29.12 & 33.90 \\
January & 28.77 & 33.69 \\
February & 26.91 & 33.76 \\
March & 26.85 & 34.46 \\
\hline
\end{tabular}

accumulated WI of $49.03 \mathrm{~g}$; in the fattening stage, the accumulated WI was $101.49 \mathrm{~g}$. In the pre-fattening stage, the condition factor $\mathrm{K}$ had an average value of 1.94 , ranging from 1.74 to 2.05 ; in the fattening stage, the value was 2.16 . In the pre-fattening stage, the specific growth rate (SGR) was 2.02, ranging from 2.65 to 1.50 ; in the fattening stage, the SGR was 1.35 . In the pre-fattening stage, the daily weight gain (DWG) was estimated at $0.44 \mathrm{~g} \mathrm{~d}^{-1}$, with a minimum value of 0.27 and a maximum value of 0.61 ; the highest DWG was recorded in the fattening stage, with $1.31 \mathrm{~g} \mathrm{~d}^{-1}$ (Table $3)$.

The proximate analysis of the test feed supplied by the fishermen during the fattening stage showed a lipid content of $20.4 \%$, protein content of $30.2 \%$, moisture content of $15 \%$ and $5 \%$ of ash content. No abnormal pathological or ethological signs were observed during the pre-fattening stage. However, the fishermen observed a strange behavior in the fish during the fattening stage, starting on day 175 of culture; it included not eating, erratic swimming and lethargy. The number of affected fish increased until massive mortality occurred during three consecutive days. During the mortality event, the fishermen asked our research group to intervene. We asked the fishermen to randomly collect 48 live fish in the fattening stage for post-mortem study. In the external inspection, 38 (80\%) of the collected fish showed body condition values of 4-5 (obese) (Fig. 1a).

The internal inspection showed that in 36 of the 48 fish collected $(75 \%)$, the gills showed discoloration, appearing light brown to white, interspersed with red areas. In the rest of the fish, the gills showed their usual coloration (dark red), with no other evident macroscopic alterations. In the 36 fish with discolored gills, the abdominal cavity had an increased amount of adipose tissue, which surrounded most of the organs (Figs. 1b-c). The liver of these 36 fish was enlarged, occupying much of the coelom. Furthermore, the liver surface contained an abundant amount of adipose tissue (Fig. 1d), which, when removed revealed that the hepatic parenchyma had a diffuse yellowish-white color, rounded edges, and friable consistency. The cutting surface was covered overall with a light-yellow color (Fig. 1d).

Moreover, the intestinal loops had an abundant amount of adipose tissue. Histopathological analyses revealed the presence of microscopic lesions in the hepatic parenchyma of $36(75 \%)$ of the 48 fish collected during the mortality event. The hepatic parenchyma also exhibited hepatic cords in disarray. Between 80 and $100 \%$ of hepatocytes were found to be degenerated and swollen, with hypochromic cytoplasm and clear, unstained vacuoles of variable size that displaced and compressed the nucleus. Furthermore, 20\% of the hepatocytes exhibited pycnosis and/or karyolysis (individual necrosis), and hepatocellular steatosis was histologically diagnosed. Hepatic or hepatocellular steatosis (HE) is a degenerative change that consists in the accumulation of triglycerides in the cytoplasm of hepatocytes, stored in the form of globules or vacuoles.

Also referred to as hepatic lipidosis or fatty liver, this condition has been described in various domestic species such as bovines, cats, dogs, horses, pigs, among others. It can have nutritional, metabolic (physiological or pathological) or toxic origin (Cullen \& Stalker, 2016; Brown et al., 2017). In captive fish, HE is the most common metabolic alteration; although its exact incidence is not known, it may comprise between 50 and $80 \%$ of all pathologies of nutritional origin (Tacon, 1996; Santos et al., 2004; Rosenthal et al., 2013). In the present study, even though all the fish sampled showed lesions consistent with hepatocellular steatosis, it was not possible to determine their incidence. Roberts \& Ellis (2012) mentions that, unlike domestic animals, liver alterations are less noticeable in fish, which agrees with the records made by the fishermen in the present study; they mentioned that no clinical alterations were observed in none of the fish until the $175^{\text {th }}$ day of the culture. The biometric and ethological data recorded during this period are considered acceptable. During the pre-fattening stage, for example, the condition factor (K) was higher, although under different conditions, than the values reported by Catacutan et al. (2001) in juveniles weighing $24.8 \mathrm{~g}$, by Abbas et al. (2005) in $8 \mathrm{~g}$ specimens of Lutjanus argentimaculatus and by Abdo de la Parra et al. (2010) in 2.2 g juvenile specimens of $L$. guttatus. In the present study (from day 175 of the culture), although there were no clinical signs indicative of liver damage, external examination revealed a slight increase in body condition that could indicate some nutritional disorder.

The necropsy found evidence of this in all the samples specimens; the macroscopic appearance of the liver coincided with what has been reported by other authors (both in fish and domestic mammals), who report that, in cases of hepatocellular steatosis, the liver 
Table 2. Body weight $(\mathrm{g})$, length $(\mathrm{cm})$ and survival $(\%)$ values recorded during the different culture stages of Lutjanus guttanus. n: number of sampled organisms, Day: days of culture, SD: standard deviation.

\begin{tabular}{|c|c|c|c|c|c|}
\hline Stage & Day & $\mathrm{n}$ & $\begin{array}{c}\text { Body weight } \pm \text { SD } \\
(\mathrm{g})\end{array}$ & $\begin{array}{l}\text { Pattern length } \pm \text { SD } \\
(\mathrm{cm})\end{array}$ & $\begin{array}{l}\text { Survival } \\
(\%)\end{array}$ \\
\hline \multirow{4}{*}{ Pre-fattening } & 0 & & 6.0 & & 100 \\
\hline & 38 & 109 & $16.14 \pm 2.17$ & $9.22 \pm 0.56$ & 98 \\
\hline & 67 & 32 & $28.78 \pm 2.21$ & $11.81=$ & 97 \\
\hline & 110 & 60 & $55.03 \pm 10.58$ & $13.88 \pm 1.25$ & 97 \\
\hline Development & 187 & 71 & $156.52 \pm 26.27$ & $19.32 \pm 1.23$ & $<20$ \\
\hline
\end{tabular}

Table 3. Biometric indexes: weight increase WI (g); condition factor K; specific growth rate SGR $\left(\% \mathrm{~d}^{-1}\right)$; daily weight gain DWG $\left(\mathrm{g} \mathrm{d}^{-1}\right)$. The values were recorded during the different culture stages of Lutjanus guttatus.

\begin{tabular}{lrcccc}
\hline Stage & Day & $\begin{array}{c}\text { WI } \\
(\mathrm{g})\end{array}$ & $\begin{array}{c}\text { Condition } \\
\text { factor K }\end{array}$ & $\begin{array}{c}\text { SGR } \\
\left(\% \mathrm{~d}^{-1}\right)\end{array}$ & $\begin{array}{c}\text { DWG } \\
\left(\mathrm{g} \mathrm{d}^{-1}\right)\end{array}$ \\
\hline \multirow{3}{*}{ Pre-fattening } & 38 & 10.14 & 2.05 & 2.65 & 0.27 \\
& 67 & 12.64 & 1.74 & 1.92 & 0.44 \\
Development & 110 & 26.25 & 2.05 & 1.50 & 0.61 \\
& 187 & 101.49 & 2.16 & 1.35 & 1.31 \\
\hline
\end{tabular}

may increase in volume, macroscopically, showing a generalized pallor or a yellow-orange color, and a consistency decrease that may even reach tissue friability (Kalogeropoulos et al., 1992; Penrith \& Bastianello, 1994; Tacon, 1996; Spisni et al., 1998; Caballero et al., 1999; Rosenthal et al., 2013; TrianaGarcía et al., 2013). Some of these authors also mention that lipid infiltration can occur in organs such as the gills, pancreas and intestine (Penrith \& Bastianello, 1994). In this case, apparent branchial lipid infiltration was macroscopically visible in 36 of the 48 fish sampled; however, this could not be corroborated histologically. Histologically, hepatocellular steatosis in fish is similar to that described in other species, which usually manifests as the presence of clear intracytoplasmic vacuoles of variable size that which cause nuclear displacement, cell swelling, disorganization of the hepatic cords and even individual cell death (Grizzle \& Kiryu, 1993; Penrith \& Bastianello, 1994; Spisni et al., 1998; Caballero et al., 1999, 2004; Santos et al., 2004; Genc et al., 2005; Passeri et al., 2009; Cullen \& Stalker, 2016; Brown et al., 2017).

It is important to point out that in some free-living species the liver plays the role of a lipid storage organ, which can store excessive amounts of lipids during some seasons of the year without it being considered a pathological disorder (Spisni et al., 1998; Roberts \& Ellis, 2012). In a study on rainbow trout (Oncorhynchus mykiss) carried out in Peru, HE appeared together with infectious type disorders (58.6\%) and with inflammatory-type conditions $(46.5 \%)$ that were associated with possible infections of bacterial origin (Rosenthal et al., 2013). However, no histological alterations that could indicate the existence conditions were found in the present study. In fish, hepatocellular steatosis has also been associated with toxic or infectious processes, or with hypoxic events (Grizzle \& Kiryu, 1993). However, the most common factors favoring the development of this pathology are usually nutritional disorders, especially those that result from lipid imbalance (Tacon, 1996), such as an increase in the lipid content of the diet, a deficiency of essential fatty acids, the use of artificial diets and the inclusion of oils of vegetable or animal origin in the diet (Kalogeropoulos et al., 1992; Caballero et al., 1999, 2002, 2004; Santos et al., 2004; Genc et al., 2005; Jia et al., 2006; Rosenthal et al., 2013). In some studies that report the presence of hepatic steatosis, the concentration of lipids in the diet ranged from 9 to $27 \%$ (Caballero et al., 1999, 2002, 2004; Genc et al., 2005; Jia et al., 2006; Rosenthal et al., 2013; Triana-García et al., 2013).

In the present study, the proximate analysis of the test feed used by the fishermen during the fattening stage showed that the average concentration of lipids was $20.4 \%$; this could be the main trigger of HE. The average protein concentration in these samples was $30.2 \%$, which would classify it as low-protein diet, compared with other studies in which the concentration of proteins required by the diet is higher than $50 \%$ (García-Ortega, 2009; Abdo de la Parra et al., 2010). Although the studies conducted on fish do not mention it, in domestic animals the lack of protein is considered a crucial factor for the development of hepatocellular 


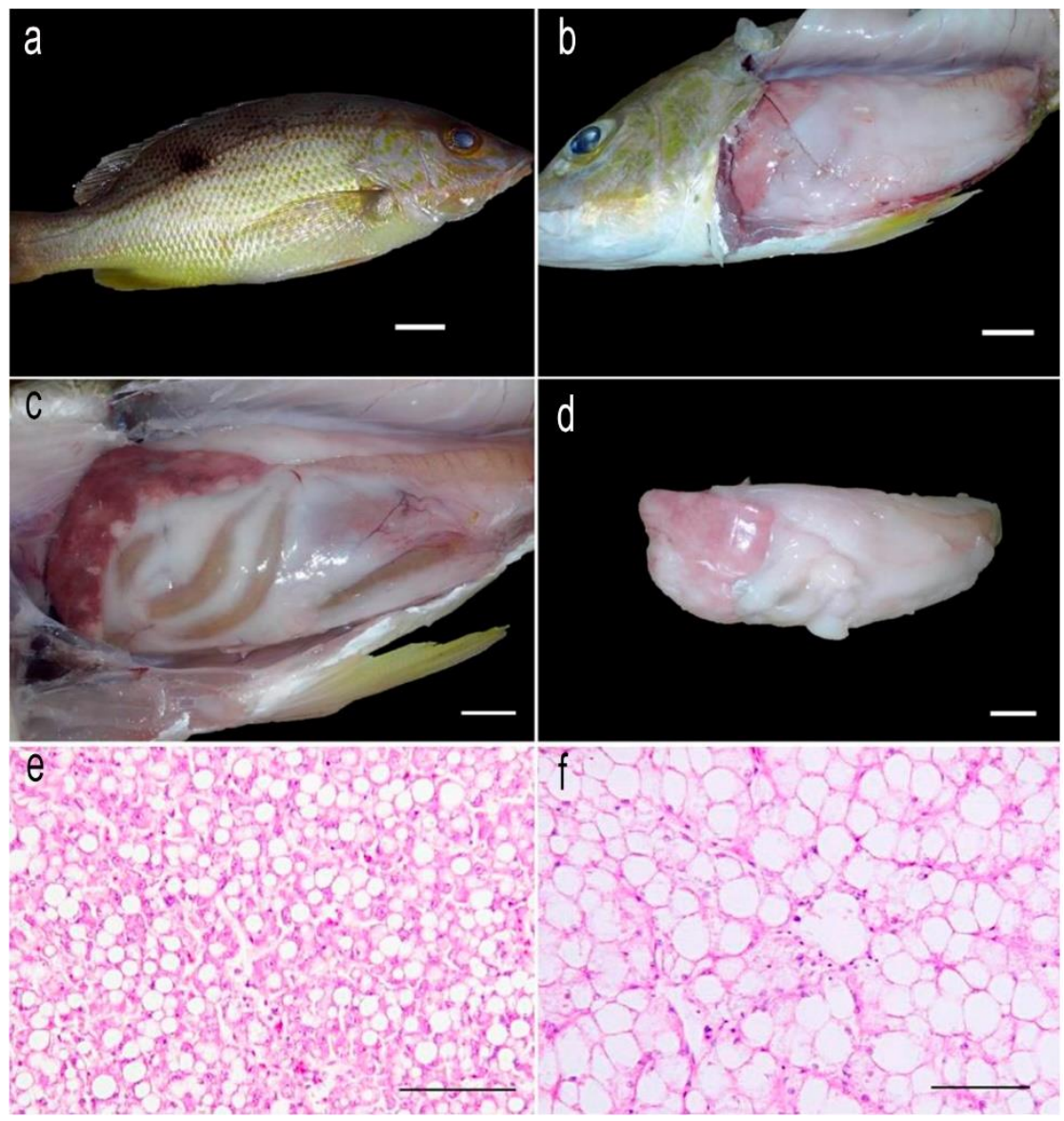

Figure 1. a) Juvenile snappers (Lutjanus guttatus) from mariculture in Manzanillo, Colima, (Mexico) were above their weight limit and exhibited increased body condition (scale bar $=1 \mathrm{~cm}$ ); b-c) an abundant amount of adipose tissue is observed by the coelomic cavity, covering the liver surface and expanding the intestinal loops $(\mathrm{scale}$ bar $=1 \mathrm{~cm})$; $\mathrm{d})$ the liver is enlarged, with a yellowish-white color and with rounded and friable edges (scale bar $=1 \mathrm{~cm})$; e) photomicrographs of the hepatic parenchyma showing disordered hepatic cords, hematoxylin and eosin (scale bar $=200 \mu \mathrm{m}$ ); f) the majority of hepatocytes are degenerated, swollen, with necrosis and hypochromic cytoplasm, showing clear, unstained vacuoles of variable size that displace and compress the nucleus, hematoxylin and eosin (scale bar $=50 \mu \mathrm{m})$.

steatosis, due to the importance of transport molecules (of protein origin) in the binding and transport of triglycerides out of hepatocytes (Cullen \& Stalker, 2016; Brown et al., 2017). Because of this, we cannot rule out that the low concentration of proteins in the diet studied here was an equally important factor for the development of the hepatocellular disorder described above.

There are no previous reports of diet-related disorders in L. guttatus. In conclusion, based on the macroscopic and histopathological findings of the liver, and the results of the proximate analysis of the test feed, it is possible to suggest that the $\mathrm{HE}$, in the specimens of L. guttatus cultivated by the group of fishermen, was strongly associated with the nutritional stress to which the fish were subjected, especially during the fattening stage. However, it is not possible to discard the influence of other factors not recorded during the culture period, such as an increase in suspended sediments and the speed of the current due to torrential rains and/or the so-called "groundswell" phenomenon, which could have also caused the acute mortality event.

Finally, it is worth mentioning that this study was based on an intervention made at the request of the group of fishermen responsible for the mariculture and that the data presented here, except for the histopathological report, were taken directly from the work records of the mariculture operators. It should also be noted that our working group had no prior knowledge of the conditions of the culture until the time of the intervention request. However, given the findings we made and the scarce information on this subject, we think this work can serve as a basis for future research. It is also necessary to mention that both Mexico and 
other countries that seek to develop and support their aquaculture sector would benefit from strengthening the links between public universities and productive operations, in order to minimize adverse effects such as those reported here.

\section{ACKNOWLEDGMENTS}

To the Faculty of Marine Sciences of the University of Colima for all the support provided for the development of this work. To Maricultura de Manzanillo SCRL, owner of the aquaculture system, for the invitation to professors of the University of Colima to participate in this study.

\section{REFERENCES}

Abbas, G., Jamil, K., Akhtar, R. \& Hong, K. 2005. Effects of dietary protein level on growth and utilization of protein and energy by juvenile mangrove red snapper (Lutjanus argentimaculatus). Journal of Ocean University of China, 4(1): 49-55.

Abdo de la Parra, M.I., Rodríguez-Ibarra, L.E., Hernández, C., Hernández, K., González-Rodríguez, B., Martínez-Rodríguez, I. \& García-Ortega, A. 2010. Efecto de diferentes niveles de proteína y lípidos totales en la dieta sobre el crecimiento y supervivencia de juveniles de pargo lunarejo Lutjanus guttatus. Revista de Biología Marina y Oceanografía, 45(3): 433-439.

Allen, G.R. 1995. Lutjanidae. In: Fischer, W., Krupp, F., Schneider, W. \& Niem, V.H. (Eds.). Guía FAO para la identificación de especies para los fines de la pesca. Vol. 3. Pacífico centro-oriental. FAO, Roma, pp. 1231-1244.

Amezcua, F., Soto-Avila, C. \& Green-Ruiz, Y. 2006. Age, growth, and mortality of the spotted rose snapper Lutjanus guttatus from the southeastern Gulf of California. Fisheries Research, 77(3): 293-300.

Barton, B.A., 2002. Stress in fishes: a diversity of responses with particular reference to changes in circulating corticosteroids. Integrative and Comparative Biology, 42: 517-525.

Brown, D.L., Van Wettere, A.J. \& Cullen, J.M. 2017. Hepatobiliary system and exocrine pancreas: metabolic disturbances and hepatic accumulations. In: Zachary, J.F. (Ed.). Pathologic basis of veterinary diseases. Elsevier, Missouri, pp. 438-441.

Bustillo-García, L., Martínez-Dávila, J.P. \& GallardoLópez, F. 2008. Sustainable rural development: that distinguished stranger (a review). Revista Científica, 1: 43-50.

Caballero, M.J., Izquierdo, M.S., Kjørsvik, E., Fernandez, A.J. \& Rosenlund, G. 2004. Histological alterations in the liver of sea bream, Sparus auratus L., caused by short or long term feeding with vegetable oils as the sole lipid source. Journal of Fish Diseases, 27: 531541.

Caballero, M.J., López-Calero, G., Socorro, J., Roo, F.J., Izquierdo, M.S. \& Fernández, A.J. 1999. Combined effect of lipid level and fish meal quality on liver histology of gilthead seabream (Sparus aurata). Aquaculture, 179(1-4): 277-290.

Caballero, M.J., Obach, A., Rosenlund, G., Montero, D., Gisvold, M. \& Izquierdo, M.S. 2002. Impact of different dietary lipid sources on growth, lipid digestibility, tissue fatty acid composition, and histology of rainbow trout, Oncorhynchus mykiss. Aquaculture, 214(1): 253-271.

Cano, A. 2003. Reproduction in captivity and cultivation of the Pacific rose spotted snapper Lutjanus guttatus in the Republic of Panama. Abstracts of the World Aquaculture Conference, Salvador, Brazil, May 1923, 2003. World Aquaculture Society, 153 pp.

Catacutan, M.R., Pagador, G.E. \& Teshima, S. 2001. Effects of dietary protein and lipid levels and protein to energy ratios on growth, survival, and body composition of the mangrove red snapper, Lutjanus argentimaculatus (Forsskal, 1755). Aquaculture Research, 32: 811-818.

Cullen, J.M. \& Stalker, M.J. 2016. Liver and biliary system: hepatocellular steatosis (lipidosis). In: Maxie, G.M. (Ed.). Jubb, Kennedy \& Palmer's pathology of domestic animals. Elsevier, Missouri, pp. 273-278.

Fitridge, I., Dempster, T., Guenther, J. \& De Nys, R. 2012. The impact and control of biofouling in marine aquaculture: a review. Biofouling, 28(7): 649-669.

García-Ortega, A. 2009. Nutrition and feeding research in the spotted rose snapper (Lutjanus guttatus) and bullseye puffer (Sphoeroides annulatus), new species for marine aquaculture. Fish Physiology and Biochemistry, 35(1): 69-80.

García-Gómez, A., de la Gándara, F. \& Raja, T. 2002. Utilización del aceite de clavo, Syzygium aromaticum L. (Merr \& Perry), como anestésico eficaz y económico para labores rutinarias de manipulación de peces marinos cultivados. Boletín del Instituto Español de Oceanografía, 18(1-4): 21-23.

Garduño, D.M., Hernández, M.M., Soto, F. \& Sánchez, Z.A. 2016. Evaluación de tres alimentos balanceados en la engorda de juveniles de pargo lunarejo Lutjanus guttatus (Pisces: Lutjanidae) en Nayarit, México. Pisces, 26(1): 87-92.

Genc, E., Yilmaz, E. \& Akyurt, I. 2005. Effects of dietary fish oil, soy-acid oil, and yellow grease on growth and 
hepatic lipidosis of hybrid tilapia fry. Israeli Journal of Aquaculture, 57(2): 90-96.

Grizzle, J.M. \& Kiryu, Y. 1993. Histopathology of gill, liver, and pancreas, and serum enzyme levels of channel catfish infected with Aeromonas hydrophila complex. Journal of Aquatic Animal Health, 5(1): 3650.

Hodson, S.L., Lewis, T.E. \& Burke, C.M. 1997. Biofouling of fish-cage netting: the efficacy and problems of in situ cleaning. Aquaculture, 152(1-4): 77-90.

Ibarra-Castro, L. \& Duncan, N.J. 2007. GnRHa-induced spawning of wild-caught spotted rose snapper Lutjanus guttatus. Aquaculture, 272: 737-746.

Jia, G., Feng, J. \& Qin, Z. 2006. Studies on the fatty liver diseases of Sciaenops ocellatus caused by different ether extract levels in diets. Frontiers of Biology in China, 1(1): 9-12.

Kalogeropoulos, N., Alexis, M.N. \& Henderson, R.J. 1992. Effects of dietary soybean and cod-liver oil levels on growth and body composition of gilthead bream (Sparus aurata). Aquaculture, 104(3-4): 293308.

Kirk, S., Sawyer, R. \& Egan, H. 1996. Composición y análisis de alimentos de Pearson. Compañía Editorial Continental, México D.F., pp. 259-268.

Olivares, O.P. \& Boza, J.B. 1999. Crecimiento de juveniles de pargo mancha (Lutjanus guttatus) utilizando alimento granulado en condiciones de laboratorio. Uniciencia, 16: 45-48.

Passeri, M.J., Cinaroglu, A., Gao, C. \& Sadler, K.C. 2009. Hepatic steatosis in response to acute alcohol exposure in zebrafish requires sterol regulatory element binding protein activation. Hepatology, 49(2): 443-452.

Penrith, M.L. \& Bastianello, S.S. 1994. Hepatic lipoidosis and fatty infiltration of organs in a captive African stonefish, Synanceja verrucosa. Journal of Fish Diseases, 17(2): 171-176.

Prophet, E. 1995. Métodos histotecnológicos. Instituto de Patología de los EEUU de América (AFIP). Registro de Patología de los EEUU de América, Washington.
Roberts, R.J. \& Ellis, A.E. 2012. The anatomy and physiology of teleosts. In: Roberts, R.J. (Ed.). Fish pathology. Wiley-Blackwell, Iowa, pp. 17-61.

Rojas, J.R., Maravilla, E. \& Chicas, B. 2004. Hábitos alimentarios del pargo mancha Lutjanus guttatus (Pisces: Lutjanidae) en Los Cóbanos y Puerto La Libertad, El Salvador. Revista de Biología Tropical, 52: 163-170.

Rosenthal, S., Sandoval, N., Gavidi, C. \& Tabacchi, L. 2013. Frecuencia de lipidosis hepática en trucha arco iris (Oncorhynchus mykiss) de fase juvenil en una piscigranja. Revista de Investigaciones Veterinarias del Perú, 120: 118-124.

Santos, A.A., Ranzani-Paiva, M.J.T., Felizardo, N.N. \& Rodrigues, E.D.L. 2004. Análise histopatológica de fígado de Tilápia-do-Nilo, Oreochromis niloticus, criada em tanque-rede na represa de Guarapiranga, Sao Paulo, Brasil. Boletim do Instituto de Pesca, 30(2): 141-145.

Segner, S., Sundh, H., Buchmann, K., Douxfils, J., Sundell, K.S., Mathieu, C., Ruane, N., Jutfelt, F., Toften, H. \& Vaughan, L. 2012. Health of farmed fish: its relation to fish welfare and its utility as welfare indicator. Fish Physiology and Biochemistry, 38: 85-105.

Spisni, E., Tugnoli, M., Ponticelli, A., Mordenti, T. \& Tomasi, V. 1998. Hepatic steatosis in artificially fed marine teleosts. Journal of Fish Diseases, 21(3): 177184.

Tacon, A.G.J. 1996. Lipid nutritional pathology in farmed fish. Archives of Animal Nutrition, 44(1): 33-39.

Triana-García, P.A., Gutiérrez-Espinosa, M.C. \& EslavaMocha, P.R. 2013. Rendimiento productivo e hígado graso en tilapia híbrida (Oreochromis spp.): influencia de dos fuentes de lípidos. Orinoquia, 17(2): 183-196.

Valverde, S. \& Boza, J.A. 1999. Inducción al desove en hembras del pargo mancha, Lutjanus guttatus (Steindachner, 1869). Uniciencia, 15-16: 65-69. 